DOI CrossRef: 10.30917/ATT-VK-1814-9588-2018-2-15

Аграрная наука - основа повышения эффрективности сельскохозяйственного производства

\title{
Agricultural science - the basis of improving the efficiency of agricultural production
}

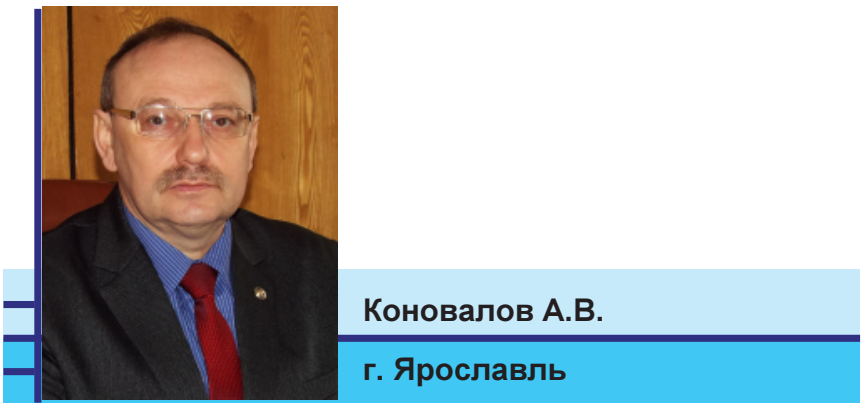

P E 3 Ю $\mathrm{M} / \mathrm{S}$ U M M A R Y

Ключевые слова: ярославская порода, молочная продуктивность, генетический потенциал, генетический тренд, аллелофонд, кормовые концентраты

Key words: Yaroslavl breed, milk productivity, genetic potential, genetic trend, allelofond, feed concentrates

В статье представлены основные направления исследований Ярославского НИИЖК - фрилиала ФНЦ "ВИК им. В.Р. Вильямса": совершенствование методов генетического контроля и управления селекционным процессом, ДНКдиагностика, иммуногенетический контроль достоверности происхождения крупного рогатого скота и разработка адаптивных технологий кормления высокопродуктивных коров и молодняка. Разработаны и внедрены в производство программы для ЭВМ и надстройки к ним, обеспечивающие наиболее эффрективное управление технологическими, селекционными и экономико-производственными процессами в животноводстве ("АРМW", "ПАВКА", "ЭЛЭК", "СТРЕСС", "РОМСЕЛ", "РАЦИОН"). Поголовье коров за исследуемый период в Ярославской области сократилось на 12718 голов или $53 \%$. Рост молочной продуктивности по породе составил +2924 кг или 51\%. Увеличилось содержание жира в молоке, а содержание белка снизилось на 0,07\% по породе и на $0,05 \%$ по племенным стадам. При оценке фенотипических и генетических зависимостей выявлена слабая положительная связь надоя и содержания жира в молоке $(r p=+0,04)$, отрицательная зависимость между надоем и белком $(\mathrm{rp}=-0,08)$, при этом компоненты молока имели отрицательную фенотипическую $(\mathrm{rp}=-0,21)$ и генотипическую связь $(\mathrm{rg}=-0,22)$. Мониторинг генетической ситуации по группам крови в хозяйствах Ярославской области выявил сокращение аллелей ярославского скота по ЕАВ-локусу и определил элиминацию основных аллелей. С помощью праймеров (AG), С и (GA), С были выявлены 55 фрагментов ДНК (34 фрагментов по (AG)9C, 21 - по (GA), С. Установлено, что при скармливании жмыха расторопши крупному рогатому скоту надой за лактацию был больше в опытных группах: в первой опытной группе на 647,0 кг (12,9\%), во второй - на 1015,7 кг (20,3\%). Живая масса телят рождённых от коров

получавших жмых расторопши в 3-месячном возрасте была больше на 10,7 кг (12,7\%); среднесуточный прирост на 99 г $(15,7 \%)$. Применение "Байкал ЭМ-1" оказывало положительное влияние на организм коров, что выражалось в снижении заболеваемости на 4-6\%, повышении поедаемости корма и увеличении молочной продуктивности на 5-8\%. Применение молока, заквашенного препаратом "ЭМ-Курунга", снижало заболеваемость молодняка на 9-12\% и повышало сохранность на 10-15\%. При скармливании нового полимикробиологического кормового концентрата сохранность до 6-месячного возраста составляла 100\%, заболеваемость снижалась на $30 \%$.

The main directions of research of the Yaroslavl Scientific Research Institute of livestock breeding and forage production - Federal State Budget Scientific Institution "Federal Williams Research Center of Forage Production and Agroecology" are improvement of methods of genetic control and management of selection process, DNA diagnostics, immunogenetic control of the origin of cattle and development of adaptive technologies for feeding high-yield cows and young animals. The researchers developed and implemented many computer programs and add-ins to them, providing the most effective control technology, selective and economical production processes in animal husbandry ("ARMW", "PAVKA", "ELEK", "STRESS", "ROMSEL", "RAZION"). The number of cows during the study period in the Yaroslavl region decreased by 12718 heads or $53 \%$. The growth of milk production was $+2924 \mathrm{~kg}$ or $51 \%$. The fat content in milk increased, and the protein content decreased by $0.07 \%$ in breed and $0.05 \%$ in breeding herds. It is established that phenotypic and genetic correlation between milk yield and fat content in milk was positive $(r p=+0,04)$; between milk yield and protein content in milk was negative $(r p=-0,08)$; between fat content and protein content in milk phenotypic and genetic correlation were negative ( $r p=-0,21$ and $r g=-0,22)$. Evaluation of frequency of occurrence of blood groups in the farms of the Yaroslavl region revealed a reduction of alleles of EAB-locus of Yaroslavl cattle and determined the elimination of the major alleles. Application of primers $(\mathrm{AG})_{9} \mathrm{C}$ and $(\mathrm{GA}){ }_{9} \mathrm{C}$ were revealed 55 DNA fragments (34 fragments on $(A G), C, 21$ - on (GA)9C. It is established that the feeding of cows to Thistle cake increased the yield per lactation in the first experimental group by $647.0 \mathrm{~kg}$ $(12.9 \%)$, in the second experimental group by $1015.7 \mathrm{~kg}(20.3 \%)$. The live weight of calves, born to cows were fed with the Thistle cake, at 3 months of age were more than $10.7 \mathrm{~kg}(12.7 \%)$; average daily gain by $99 \mathrm{~g}(15.7 \%)$. The use of "Baikal EM-1" had a positive impact on the body of cows, morbidity of cows decreased by $4-6 \%$, feed intake increased and milk productivity increased by $5-8 \%$. The use of milk fermented with "EMKurunga" reduced the morbidity of young animals by $9-12 \%$ and increased safety by $10-15 \%$. It was stated that feeding of the new polymicrobiological fodder concentrate to the calves

\section{Информация об авторах / Information about the authors}

Коновалов А.В., канд с.-х.наук, доцент, ВРИО руководителя, e-mail: yaniizhk@yandex.ru

Ильина А.В., канд с.-х.наук, ведущий научный сотрудник

Абрамова М.В., канд с.-х.наук, старший научный сотрудник

Алексеев А.А., старший научный сотрудник

Ярославский НИИЖК- филиал ФНЦ "ВИК им. В.Р.Вильямса"

Konovalov A., Ilyina A., Abramova M., Alekseev A. 
from 5-day to 4 months of age allowed to have the safety of this calves in the 6 months of age equal $100 \%$, morbidity was reduced by $30 \%$.

Ярославский научно-исследовательский институт животноводства и кормопроизводства создан в 1969 году на базе Всесоюзной станции животноводства и Ярославской государственной сельскохозяйственной опытной станции.

В соответствии с приказом Федерального агентства научных организаций России от 17 февраля 2017 г. № 102 и Уставом Центра, утвержденным ФАНО России от 06 декабря 2017 № 927 институт приобрел статус филиала Федерального государственного бюджетного научного учреждения "Федеральный научный центр кормопроизводства и агроэкологии имени В.Р. Вильямса".

В текущий период численный состав сотрудников института составляет 50 человек. В выполнении государственного задания в этом году приняли участие 27 исследователей, в том числе 2 доктора и 10 кандидатов наук; удельный вес исследователей в возрасте до 39 лет в общей численности исследователей учреждения - 51,8\%.

Основными направлениями исследовательской программы института являются совершенствование методов генетического контроля и управления селекционным процессом с целью повышения продуктивности сельскохозяйственныхживотных, ДНК-диагностика маркеров хозяйственно-полезных признаков сельскохозяйственных животных и генов наследственных заболеваний, иммуногенетический контроль достоверности происхождения крупного рогатого скота, разработка адаптивных технологий кормления высокопродуктивных коров и молодняка, разработка технологий производства зерновых, силосных и травянистых кормов в севообороте при сохранении и повышении плодородия почвы.

Одним из направлений прикладных исследований института является разработка информационных технологий, применимых в животноводстве при управлении технологическими и селекционными процессами. В результате создана программа для ЭВМ "APM W", которая помимо первичного учета и бонитировки выполняет оценку популяционно-генетических параметров, быков, линий, межлинейных кроссов, ранжирование стада по продуктивности в разрезе отдельных линий, быков-производителей, ферм, выделяются материнские семейства, строятся их схемы. В настоящее время к ядру программы разработаны базовые надстройки контроля инбридинга, определения генетического превосходства, подбора родительских пар с учетом показателей групп крови, программа "ПАВКА" (ПолуАВтоматическаяКАртотека быков), программа "ЭЛЭК" (ЭЛитныйЭКстерьер) обеспечивающая комплексный подход к оценке и отбору по экстерьеру и продуктивности, для оценки и отбора стрессоустойчивых генотипов создана базовая надстройка "СТPЕСС" [1, 2, 3].

С 2001 года в институте и ряде племенных хозяйств используется программный комплекс "РОМСЕЛ", основная задача которого - решение задач по селекции романовских овец. В 2010 году коллектив разработчиков программы удостоен серебряной медали ВВЦ [4].

Для оптимизации реализации генетического потенциала высокопродуктивных стад разработана программа "РАЦИОН". Расчет и балансирование рационов осуществляется по детализированным нормам кормления и результатам анализов кормов хозяйства. Одновременно рассчитываются зоотехнические и экономические характеристики рациона. В 2014 году коллектив разработчиков удостоен бронзовой медали ВВЦ [5]

С целью изучения селекционных изменений в ярославской породе крупного рогатого скота проведен анализ показателей молочной продуктивности на протяжении трех генерационных интервалов матерей коров (таблица 1) [6,7,8].

Как мы видим, поголовье животных ярославской породы в Ярославской области сократилось в 2016 году по сравнению с 2000 на 12718 голов или 53 \%. При этом происходило наращивание поголовья коров в племенных хозяйствах и к 2000 году составило 104,2\%.

Произошел значительный рост молочной продуктивности. Увеличение продуктивности в 2016 году по сравнению с 2000 по породе составило 2924 кг или $+51 \%$, по племенным стадам 2290 кг или 63,4\%. Повышение содержания жира в молоке произошло как за счет направленной селекционно-племенной работы с породой, так и внедрением новых кормов и технологий кормления. За последние шесть лет содержание белка снизилось на 0,07\% по породе и на 0,05\% по племенным стадам.

При разработке селекционных программ необходимым элементом является выявление фенотипических и генетических зависимостей основных продуктивных признаков $[9,10]$. При оценке френотипических и генетических зависимостей выявлена слабая положительная связь надоя и содержания жира в молоке $\left(r_{p}=+0,05\right)$, отрицательная зависимость между надоем и белком $\left(r_{p}=-0,23\right)$, при этом компоненты молока имели положительную фенотипическую $\left(r_{p}=+0,22\right)$ и генотипическую связь $\left(r_{g}=+0,11\right)$. Оценка зависимостей в 2016 году показала, что фенотипическая связь между надоем и содержанием жира в молоке снизилась, а генетическая и вовсе поменяла знак, и от слабо положительной $\left(r_{g}=+0,12\right)$ стала слабо отрицательной $\left(r_{g}=-\right.$ $0,06)$. Данное явление, скорее всего, объясняется увеличением количества помесных животных и их кровности по голштинской породе. Для подтверждения или опровержения предварительных выводов привлечена информация по иммуногенетическим показателям.

В селекции крупного рогатого скота группы крови используют для решения ряда задач, способствующих повышению эффективности племенной работы. С их помощью можно проводить: генетическую экспертизу достоверности записей происхождения (в родословных племенных животных), характеристику генофонда и генетической структуры стада или породы, определение селекционной и генетической дифференциации групп животных, контроль наследования особенностей выдающихся животных; определение коэффиициента генетического сходства между селекционируемыми группами животных, прогнозирование эффекта гетерозиса, подбор родительских пар с целью получения животных желательных генотипов.

Мониторинг генетической ситуации по группам крови в хозяйствах Ярославской области проводится с 1967 года.

В период 1967-1977 гг. у ярославского скота по ЕAВлокусубыло выявлено 57 аллелей, из них 19 В-аллелей с суммарной генной частотой 0,9045 имели относительно высокую концентрацию: BGKY $D^{\prime} E^{\prime} F^{\prime}(0,0102)$, BGKE'F'O' $(0,0229), B_{1}(0,0513), B Q T_{1} A^{\prime} F^{\prime}(0,0128), B Q T_{2} G^{\prime} P^{\prime} B^{\prime \prime}(0,0209)$, BY $\mathrm{G}^{\prime} Y^{\prime}(0,0222)$, BI'P'G'Y' $(0,0715), \mathrm{GO}_{1}(0,0240), \mathrm{I}_{1}(0,0243)$, $\mathrm{I}_{2}(0,0826), \mathrm{O}_{1}(0,0570), \mathrm{O}_{1} \mathrm{~T}_{1} \mathrm{E}_{3}^{\prime} \mathrm{F}^{\prime} \mathrm{I}^{\prime} \mathrm{K}^{\prime}(0,0120), \mathrm{O}_{1} \mathrm{D}^{\prime}(0,0756)$, $P_{1} I^{\prime}(0,0619), A^{\prime}(0,0434), A^{\prime} O^{\prime}(0,0462), B^{\prime} E_{3}^{\prime} G^{\prime}(0,0203)$, $D^{\prime} E_{3}^{\prime} F^{\prime} G^{\prime} O^{\prime}(0,0468), b(0,1986)$.

2000-2005 гг. аллелофонд ярославской породы скота по ЕАВ-локусу представлен 83 аллелями, из них 24 Валлеля с суммарной генной частотой 0,8269 имели относительно высокую концентрацию: BGKY ${ }_{2} E^{\prime} F^{\prime}(0,0102)$, BGKE'F'O' (0,0203), BGE'O' (0,0101), B I'P'Q'Y' $(0,0850), B_{1} O_{1}$ $(0,0519), B_{2} G^{\prime} Y^{\prime} G^{\prime}(0,0372), B Q T_{2} G^{\prime} P^{\prime} B^{\prime \prime}(0,0209), G_{2} O_{2} E^{\prime}$ $(0,0250), C_{2} Y_{2} E_{3}^{\prime} Q^{\prime}(0,0110), C_{2} Y_{2} E_{3}^{\prime} O^{\prime}(0,0542), I_{1}(0,0160), I_{2}$ $(0,1440), O_{1} T_{1}^{2} E_{3}^{\prime} F^{\prime} I^{\prime} K^{\prime}(0,0120), O_{1} Y_{2}^{3}(0,0120), O_{1} Y_{2} Y^{\prime}(0,0160)$, $\mathrm{O}_{1} \mathrm{~A}^{\prime}(0,0160), \mathrm{O}_{2} \mathrm{D}^{\prime}(0,0242), \mathrm{P}_{1} \mathrm{E}_{3}^{\prime} \mathrm{I}^{\prime}(0,0630), Y_{2} \mathrm{~A}_{1}^{\prime}(0,0220)$, $\mathrm{B}^{\prime} \mathrm{E}_{3}^{\prime} \mathrm{G}^{\prime}(0,0203), \mathrm{D}^{\prime} \mathrm{E}_{3}^{\prime} \mathrm{F}^{\prime} \mathrm{G}^{\prime} \mathrm{O}^{\prime}(0,0468), \mathrm{G}^{\prime} \mathrm{I}^{\prime}(0,0102), \mathrm{b}(0,0986)$.

За последний период времени (2010-2017 гг.) у ярославского скота выявлено 72 аллеля по EAB-локусу. Проведенные исследования показывают, что во всех стадах Ярославской области основной удельный вес имеют животные с ЕАВ-системами групп крови: $\mathrm{Y}_{2} \mathrm{~A}^{\prime}{ }_{2}(0,1540)$, $G_{2} Y_{2} E_{3}^{\prime} Q^{\prime}(0,10610), I_{2}(0,1740), P_{2} l^{\prime}(0,1000)$, b $(0,0743)$, $\mathrm{I}_{1}(0,0649), \mathrm{D}^{\prime} \mathrm{E}_{3} \mathrm{~F}_{2}^{\prime} \mathrm{G}^{\prime} \mathrm{O}^{2}(0,0627), \mathrm{O}_{4}(0,0357), \mathrm{Q}^{\prime}(0,0322), \mathrm{B}_{2} \mathrm{O}_{2}$ $(0,0275), B_{2} Y_{2} E^{\prime}{ }_{3} G^{\prime} Y^{\prime}(0,0206), \quad G_{2} O_{2} E_{3}^{\prime}(0,0202), G_{2} O_{4} Y_{2}$ $(0,0189), \mathrm{O}_{4} \mathrm{D}^{\prime}(0,0185), \mathrm{B}_{2} \mathrm{I}^{\prime} \mathrm{P}^{\prime} \mathrm{Q}^{\prime} Y^{\prime} \quad(0,0176), \mathrm{Y}_{2} \mathrm{D}^{\prime} \mathrm{E}^{\prime}{ }_{3}$ 
$(0,0176), \mathrm{B}_{2} \mathrm{O}_{4} \mathrm{~B}^{\prime}(0,0172), \mathrm{G}_{2} \mathrm{O}_{4}(0,0103), \mathrm{B}_{2} \mathrm{O}_{4} \mathrm{Y}_{2} \mathrm{D}^{\prime}(0,0099)$, G" (0,0099), $\mathrm{E}_{2}^{\prime} \mathrm{G}^{\prime \prime}(0,0095)$.

Наметилась отчетливая тенденция к перераспределению лидерства ряда аллелей групп крови: $I_{2}(0,1740), Y_{2} A_{2}^{\prime}$ $(0,1540), G_{2} Y_{2} E_{3}^{\prime} Q^{\prime}(0,10610), P_{2} I^{\prime}(0,1000)$. Концентрация частоты встречаемости этих аллелей имеет высокие показатели, а это ведет к снижению генетического разнообразия, и как следствие происходит ослабление адаптационных возможностей, понижается устойчивость к заболеваниям и плодовитость, уменьшается продолжительность использования животных.

В настоящее время наблюдается элиминация основных аллелей: BGKY $D^{\prime} E^{\prime} F^{\prime}$, BGKE'F'O', BQT, $A^{\prime} P^{\prime}, B_{2} T_{2} G^{\prime} P^{\prime} B "$, $B Y_{2} G^{\prime} Y$ ', BI'P'G'Y', O $T_{1} E_{3} F^{\prime} I^{\prime} K$ ' (аллели выявленные в период 1967-1977 гг.); $\mathrm{B}_{2} \mathrm{G}_{2} \mathrm{E}_{2}^{\prime} \mathrm{O}^{\prime}, \mathrm{B}_{2} \mathrm{QT}_{2} \mathrm{G}^{\prime} \mathrm{P}^{\prime} \mathrm{B}^{\prime \prime}, \mathrm{C}_{2} \mathrm{Y}_{2} \mathrm{E}_{3}^{\prime} \mathrm{O}^{\prime}, \mathrm{O}_{1} \mathrm{Y}_{2} \mathrm{Q}^{\prime}$, $\mathrm{O}_{1} \mathrm{Y}_{2} \mathrm{Y}^{\prime}, \mathrm{P}_{1} \mathrm{~A}_{1}^{\prime} \mathrm{E}_{3}^{\prime} \mathrm{I}^{\prime}, \mathrm{G}^{\prime} \mathrm{I}^{\prime}$ (аллели выявленные в период 20002005 гг.).

Методом ISSR- анализа исследовано генетическое разнообразие популяции крупного рогатого скота ярославской породы Ярославской области. С помощью праймеров $(\mathrm{AG}), \mathrm{C}$ и (GA), С были определены специфические спектры фрагментов ДНК в диапазоне от 2100 до 260 п.н. Всего по двум праймерам было выявлено 55 фрагментов ДНК (34 фррагментов по (AG) ${ }_{9} \mathrm{C}, 21-$ по (GA) $\left.{ }_{9} \mathrm{C}\right)$.

Основные научные исследования в области животноводства направлены на разработку новых и совершенствование существующих технологий производства молока и мяса. В частности выполняются работы по оптимизации кормления высокопродуктивных животных, выращиванию ремонтного молодняка на основе усовершенствованных норм и рационов, внедрению перспективных кормовых средств и добавок нового поколения.

Проведенный анализ заболеваемости по Ярославской области показал, что этот показатель из года в год колеблется в пределах 38,4\%-60\%, падёж и вынужденный убой в пределах 3,4\%-9,1\%. Заболеваемость молодняка от числа всего заболевшего поголовья колеблется в пределах $32,7 \%-41,2 \%$, падёж и вынужденный убой от числа заболевшего молодняка - 5,6\%-13,2\%. Срок хозяйственного использования коров составляет 2,5-3,0 лактации, причём от 10\% до $30 \%$ первотёлок гибнут в первый месяц после отёла, то есть корова не оправдывает своё выращивание [11].

В целях профилактики заболеваний животных целесообразно применение в кормлении компонентов, нормализующих работу печени, а именно применение гепатопротекторов растительного происхождения, одним из которых является растение Расторопша пятнистая (Silybummarianum).

Исследования по применению жмыха расторопши в качестве биологически активной добавки в рационах проводились в ОАО "Племзавод имени Дзержинского" Ярославского района Ярославской области. Жмых расторопши скармливали до конца первой лактации, 1 раз в сутки с комбикормом ежедневно в течение 45-и суток с перерывом на 45 суток. Контрольная группа получала основной рацион (ОР), первая опытная - OP + 400 мг/кг живой массы жмыха расторопши, вторая опытная - ОР + 600 мг/кг живой массы.

В контрольной группе до отёла заболевания регистрировались у 4-х (20\%) животных, в опытных - по одной (5\%) в каждой группе, то есть заболеваемость в этих группах была меньше на 15\%. Сохранность в контрольной группе составила $90 \%$, в опытной 100\%. Молочная продуктивность коров в группах представлена в таблице 2.

Данные таблицы 2 показывают, что надой за лактацию был больше в опытных группах: в первой опытной группе на 647,0 кг (12,9\%), во второй - на 1015,7 кг (20,3\%). Массовая доля жира и белка была практически одинаковой и колебалась в пределах 4,59-4,60\% и 3,20-3,22\%, соответственно.

Живая масса телят рождённых от коров, получавших

Таблица 1. Изменение продуктивности по породе в динамике

\begin{tabular}{|c|c|c|c|c|c|c|}
\hline \multicolumn{3}{|c|}{ (2) } & \multirow{2}{*}{$\begin{array}{c}\text { Поголовье } \\
27068\end{array}$} & \multirow{2}{*}{$\begin{array}{c}\text { Надой, } \\
\text { кг }\end{array}$} & \multirow{2}{*}{$\begin{array}{c}\text { Содержание } \\
\text { жира, \% } \\
4,07\end{array}$} & \multirow{2}{*}{$\begin{array}{c}\text { Содержание } \\
\text { белка, \% } \\
-\end{array}$} \\
\hline 2000 & Пробонитирова & Bcero & & & & \\
\hline & В т.ч. по племстадам & Bcero & 10119 & 3974 & 4,14 & - \\
\hline \multirow[t]{2}{*}{2006} & \multicolumn{2}{|c|}{ Пробонитировано коров всего } & 26246 & 4025 & 4,14 & - \\
\hline & В т.ч. по племстадам & Bcero & 11783 & 4932 & 4,22 & - \\
\hline \multirow[t]{2}{*}{2010} & \multicolumn{2}{|c|}{ Пробонитировано коров всего } & 20200 & 4689 & 4,25 & 3,19 \\
\hline & В т.ч. по племстадам & Bcero & 14600 & 5286 & 4,37 & 3,20 \\
\hline \multirow[t]{2}{*}{2016} & \multicolumn{2}{|c|}{ Пробонитировано коров всего } & 14350 & 5972 & 4,31 & 3,12 \\
\hline & В т.ч. по племстадам & Bcero & 10545 & 6264 & 4,49 & 3,15 \\
\hline
\end{tabular}

Таблица 2. Молочная продуктивность коров

\begin{tabular}{|l|c|c|c|}
\hline \multicolumn{2}{|c|}{ Показатели } & \multicolumn{3}{c|}{ Группы } \\
\cline { 2 - 4 } & контрольная & опытная 1 & опытная 2 \\
\hline Продолжительность лактации, сутки & $289,6 \pm 3,1$ & $306,1 \pm 2,7$ & $303,4 \pm 1,9$ \\
\hline Надой за лактацию, кг & $5015,9 \pm 97,4$ & $5662,9 \pm 80,5$ & $6031,6 \pm 89,9$ \\
\hline Среднесуточный удой, кг & $17,32 \pm 1,11$ & $18,50 \pm 0,97$ & $19,88 \pm 0,88$ \\
\hline Массовая доля жира, \% & $4,59 \pm 0,24$ & $4,60 \pm 0,17$ & $4,59 \pm 0,12$ \\
\hline Массовая доля белка, \% & $3,22 \pm 0,11$ & $3,20 \pm 0,07$ & $3,21 \pm 0,91$ \\
\hline
\end{tabular}

Таблица 3. Живая масса телят с рождения до 6-месячного возраста

\begin{tabular}{|c|c|c|c|c|c|c|c|}
\hline \multirow[t]{2}{*}{ Показатели } & \multicolumn{3}{|c|}{ Группы } & \multicolumn{2}{|c|}{$2-я \pm$ к 1-й } & \multicolumn{2}{|c|}{$3-я \pm \kappa 1-и ̆$} \\
\hline & 1-контроль & 2-опыт & 3-опыт & $\mathrm{Kr}$ & $\%$ & $\mathrm{kr}$ & $\%$ \\
\hline \multicolumn{8}{|c|}{ Живая масса: } \\
\hline при рождении & $32,0 \pm 1,89$ & $32,7 \pm 2,13$ & $32,9 \pm 2,62$ & $+0,7$ & $+2,18$ & $+0,9$ & $+2,81$ \\
\hline В 1 месяц & $46,4 \pm 3,04$ & $48,4 \pm 2,29$ & $50,8 \pm 1,19$ & $+2,0$ & $+4,31$ & $+4,4$ & $+9,48$ \\
\hline в 2 месяца & $62,7 \pm 4,29$ & $65,8 \pm 2,52$ & $70,2 \pm 2,72$ & $+3,1$ & $+4,94$ & $+7,5$ & $+11,96$ \\
\hline в 3 месяца & $77,7 \pm 5,02$ & $84,8 \pm 2,29$ & $89,5 \pm 3,64$ & $+7,1$ & $+9,14$ & 11,8 & $+15,18$ \\
\hline в 4 месяца & $94,3 \pm 5,47$ & $102,0 \pm 3,96$ & $109,6 \pm 4,58$ & $+7,7$ & $+8,16$ & $+15,3$ & $+16,22$ \\
\hline в 5 месяцев & $111,4 \pm 4,67$ & $117,7 \pm 3,67$ & $126,0 \pm 6,09$ & $+6,3$ & $+5,65$ & $+14,6$ & $+13,10$ \\
\hline в 6 месяцев & $128,9 \pm 4,80$ & $135,6 \pm 4,05$ & $142,5 \pm 5,45$ & $+6,7$ & $+5,19$ & $+13,6$ & $+10,55$ \\
\hline \multicolumn{8}{|c|}{ Среднесуточный прирост живой массы, г } \\
\hline В 1 месяц & $480 \pm 46,4$ & $523 \pm 33,6$ & $596 \pm 43,7$ & +43 & $+8,95$ & +116 & $+24,16$ \\
\hline в 2 месяца & $503 \pm 39,1$ & $543 \pm 37,1$ & $611 \pm 44,4$ & +40 & $+7,95$ & +108 & $+21,47$ \\
\hline в 3 месяца & $502 \pm 32,6$ & $572 \pm 37,5$ & $622 \pm 34,0$ & +70 & $+13,94$ & +120 & $+23,90$ \\
\hline в 4 месяца & $511 \pm 33,1$ & $568 \pm 33,7$ & $629 \pm 26,3$ & +57 & $+11,15$ & +118 & $+23,09$ \\
\hline В 5 месяцев & $522 \pm 35,9$ & $559 \pm 26,2$ & $613 \pm 23,4$ & +37 & $+7,09$ & +91 & $+17,43$ \\
\hline в 6 месяцев & $532 \pm 29,8$ & $565 \pm 22,5$ & $602 \pm 23,7$ & +33 & $+6,20$ & +70 & $+13,15$ \\
\hline
\end{tabular}


жмых расторопши, по сравнению с аналогами, во все возрастные периоды была больше, в 3-месячном возрасте на 10,7 кг (12,7\%); среднесуточный прирост на 99 г (15,7\%).

В настоящее время во всем мире происходит постепенный переход от интенсивных техногенных способов увеличения продуктивности и сохранения здоровья животных к биологическим. Биологический способ использует полезные микроорганизмы для лечения, профилактики заболеваний, повышения продуктивности и дезинфекции помещений. Эти микроорганизмы называют эффеективными микроорганизмами (ЭМ), а препараты, полученные на их основе - ЭМ-препараты, поэтому технология называется ЭМ-технология [13].

Внедрение ЭМ-технологий осуществлялось сотрудниками в животноводческих хозяйствах Ярославской области: в ООО "Новое Щедрино" коровам добавляли в силос препарат "Байкал ЭМ-1" из расчета 30 г на голову и "ЭМКурунга" - молодняку крупного рогатого скота из расчета 500 мл на голову, заквашивая им молоко. Было зарегистрировано снижение заболеваемости на 4-6\%, повышение поедаемости корма и увеличение молочной продуктивности на 5-8\%. Применение молока, заквашенного препаратом "ЭМ-Курунга", снижало заболеваемость молодняка на 9-12\% и повышало сохранность на $10-15 \%$.

В настоящее время создан новый полимикробиологический кормовой концентрат (НПКК) для животных готовый к применению для "заселения" желудочно-кишечного тракта полезной микрофрлорой. Он представляет собой культуральную жидкость с приятным запахом, желто-коричневого цвета, в виде суспензии, содержащую молочнокислые бактерии, пропионовокислые бактерии, бифидобактерии и другую полезную микрофлору.

Исследования проводились в ОАО "Племзавод имени Дзержинского" Ярославской области. Было подобрано в возрасте 4-5 суток 30 тёлочек ярославской породы улучшенного генотипа и сформировано по принципу пар-аналогов 3 группы по 10 голов в каждой. Животные находились в одинаковых условиях содержания, получали одинаковый основной рацион (ОР). Первая группа - (контрольная) получала рацион хозяйства; 2-я и 3-я - (опытные) ОР + НПКК с 5-х суток жизни раз в сутки в течение 4-х месяцев (опытные группы отличались по дозировке добавки). На 5-6-м месяце НПКК не скармливали, но в течение этих месяцев изучали наличие или отсутствие его последействия. Динамику живой массы и среднесуточного прироста живой массы в возрастном аспекте характеризует таблица 3.

Данные таблицы 3 показывают, что в каждый возрастной месяц живая масса в опытных группах была больше, чем в контрольной, и, что особенно важно, с каждым возрастным месяцем разница между группами увеличивалась и в 4-месячном возрасте превышала во 2-й группе на 7,7 кг $8,16 \%(p>0,05)$, в третьей на 15,3 кг - 16,22\%. $(p<0,05)$, по сравнению с контрольной.

Результаты исследований показали, что при скармливании НПКК телятам с 5-дневного до 4-месячного возраста не зависимо от изученных доз сохранность до 6-месячного возраста составляла 100\%, заболеваемость снижалась на $30 \%$. Полученные данные позволили сделать заключение о том, что скармливание нового полимикробиологического кормового концентрата (НПКК) оказывало положительное влияние на организм, что выражалось в активизации приёма корма, ускорении роста, прироста живой массы, снижения заболеваемости и повышения сохранности.

\section{Литература}

1.Свидетельство № 2009613920. "Автоматизированное рабочее место селекционера(АРM W): программа для ЭВМ /Косяченко Н.M, Корнилов И.А., Красавина Н.И.

2.Свидетельство 2009352130. "ЭлЭК": программа для ЭВМ /Косяченко Н.М. Красавина Н.И.

3.Программа для ЭВМ "СТРЕСС" / Косяченко Н.М., Ильина А.В. 4. Свидетельство 2009616943. "РОМСЕЛ": программ для ЭВМ / Костылев М.Н., Медянцев В.А., Красавина Н.И.

5. Свидетельство 2013613596."РАЦИОН": программа для ЭВМ / Муратов В.И. Лапин Н.В.

6.Ежегодник по племенной работе в молочном скотоводстве в хозяйствах Российской Федерации (2006 год) / И.М. Дунин, И.К. Рождественский, Х.А. Амерханов и др. // М.: изд-во ВНИИплем, 2017. - 222 c.

7.Ежегодник по племенной работе в молочном скотоводстве в хозяйствах Российской Федерации (2010 год) / И.М. Дунин, В.В. Шапочкин, Х.А. Амерханов и др. // М.: изд-во ВНИИплем, 2011 - 282 c.

8.Ежегодник по племенной работе в молочном скотоводстве в хозяйствах Российской Федерации (2016 год) / И.М. Дунин, Х.А. Амерханов, Г.Ф. Сафина и др. // М.: изд-во ВНИИплем, 2017. - 270 c.

9. Система управления селекционным процессом и генетическим потенциалом в стадах ярославского скота / В.Ф. Максименко, Н.М. Косяченко, Н.С. Фураева, М.В. Абрамова, Н.А. Тарасенкова, Н.И. Красавина. Ярославль, 2005, 132 с.

10.Свидетельство №2013620064. "Информационная база данных по ярославской породе крупного рогатого скота": база данных / Косяченко Н.М., Коновалов А.В., Фураева Н.С.

11. Сведения о незаразных болезнях / Отчет 2015 г. // Комитет ветеринарии департамента агропромышленного комплекса и потребительского рынка Ярославской области. 2016. - 17 с.

12. Муратова, Н.С. Влияние структурных углеводов на молочную продуктивность и воспроизводительные качества коров / Н.С.Муратова, В.В.Танифа, В.Л.Лукичев // Современные наукоемкие технологии. Региональное приложение. 2016. №4 (48). С. 121-125.

13. Кравайнис, Ю.Я. ЭМ-препараты и обоснование апробации нового полимикробиологического кормового концентрата в животноводстве / Ю.Я.Кравайнис, Р.С.Кравайне, А.В.Коновалов, А.В.Ильина, А.А.Алексеев // Вестник АПК Верхневолжья. 2017. №3(39). C. 48-53. 